\title{
Pengaruh Perceraian Orang Tua Terhadap Perkembangan Kepribadian Anak Usia 12-14 Tahun Di Panti Asuhan Cipta Pahlawan Makassar
}

\author{
Yohana Padafani
}

\begin{abstract}
Abstrak
Tujuan Penulisan skripsi adalah untuk mengetahui sejauh mana pengaruh perceraian orang tua terhadap kepribadian anak usia 12-14 tahun di Panti Asuhan Cipta Pahlawan Makassar. Adapun hasil penelitian dapat disimpulkan sebagai berikut: Pertama, kepribadian anak menjadi baik apabila anak melihat nilai kepribadian yang baik dari orangtuanya, karena orangtua merupakan figur yang utama bagi pembentukan emosi, rohani, sosial dan mental anak. Kedua, anak yang orang tuanya bercerai cenderung pendiam, pemalu, pemarah, minder, tidak suka bergaul, lamban untuk berfikir, trauma yang berkepanjangan dan tidak bertumbuh kerohaniannya. Ketiga, pembina merupakan salah satu metode/desain pengajaran yang dapat membawa pengaruh yang baik untuk pertumbuhan kerohanian bagi anak-anak Panti Asuhan Cipta Pahlawan Makassar. Keempat, dalam Panti Asuhan harus memiliki seorang suatu wali atau seorang konselor yang bisa menjadi pendengar yang baik anak usia dini.
\end{abstract}

Kata-kata Kunci: Pengaruh, Perceraian, Orang Tua, Perkembangan, Kepribadian, Anak, Usia 12-14 Tahun.

\section{Pendahuluan}

\section{Latar Belakang Masalah}

Belakangan ini banyak masalah yang kerap kali terjadi dalam kalangan keluarga. Salah satu masalah yang sangat nampak adalah adanya peningkatan angka perceraian. Masalah perceraian dikalangan keluarga sekarang ini sangat sukar dihindari dan dikendalikan.

Salah satu di Panti Asuhan Cipta Pahlawan yang penulis melihat bahwa anakanak dari korban perceraian orang tua sangat banyak dan sangat memprihatinkan, karena mereka yang sebelum berada di Panti Asuhan Cipta Pahlawan, kehidupan 
mereka sangat buruk baik dalam pergaulan mereka maupun kehidupan sehari-hari, dan ini adalah kesaksian dari tiap-tiap anak yang mengalami korban perceraian orang tua.

Menurut penyelidikan para ahli telah terbukti, bahwa anak-anak yang terganggu jiwanya dan nakal adalah anak-anak dari keluarga yang berantakan. Anak-anak yang orang tuanya bercerai lebih banyak terlibat dalam kenakalan dan kejahatan, baik secarai individu maupun kelompok, terkadang ditunjukkan pula bahwa anak-anak dari hasil perceraian cenderung untuk lebih mudah menemui kegagalan dalam kehidupan perkawinannya sendiri. ${ }^{1}$

Dari penjelasan diatas dapat kita lihat dan dengar melalui media, bahwa kebanyak anak-anak yang terlibat dalam kenakalan dan kriminalitas yang tinggi adalah anak-anak dari kalangan yang ekonomi rendah dan juga dari keluarga yang terpisah. Demikian pula dengan angka bunuh diri, akibat dari tidak tahan menjalani kehidupan tumah tangga yang selalu menuntut akan kebutuhan-kebutuhan dan menghadapi setiap masalah demi masalah. Menurut Benyamin Spock dalam bukunya Raising Children in A Difficult Time, kriminalitas tinggi yang dilakukan oleh anak adalah apa yang mereka melihat dari kehidupan kedua orangtuanya, bahwa apa yang dilakukan oleh ayahnya terhadap ibunya dengan perlakukan keras demikian juga sebaliknya perlakuan ibunya terhadap ayahnya adalah benar dan dia juga biasa melakukannya kepada siapapun, karena tidak ada yang salah akan hal itu. Stephen Tong mengatakan Pada tahun 1965, PBB melakukan satu konperensi yang menyelidiki mengapa banyak anak yang nakal dan mempunyai angka kriminalitas yang tinggi. Akhirnya mereka menemukan bahwa salah satu dari beberapa sebab yang paling penting, yaitu system keluarga atau kedua orang tua apabila system keluarga yang kuat maka akan menghasilkan anak-anak yang baik, tetapi keluarga yang tidak mementingkan sistem yang kuat, maka anak-anak pun akan berdampak buruk dalam kehidupannya ${ }^{2}$ Orang tua adalah kunci dari kesuksesan anaknya, apabila orang tua sadar akan hal ini pasti mereka tidak mengambil keputusan untuk bercerai. Tetapi kita dapat melihat pada orang tua sekarang, bagaimana mereka mengambil keputusan bercerai tanpa berfikir akan masa depan anaknya.

Perceraian bukanlah ideal Allah, jelaslah bahwa Allah tidak merancangkan perceraian, sebab Allah berfirman kepada Maleakhi" Aku membenci perceraian. Maleakhi 2:16,"sebab Aku membenci perceraian, FirmanTuhan, Allah Israel juga orang yang menutupi pakaiannya dengan kekerasan, Firman Tuhan semesta alam, maka jagalah dirimu dan jangan berkhianat. Yesus berkata bahwa Allah mengizinkan tetapi tidak perna memaksudkan perceraian.

\footnotetext{
${ }^{1}$ Norman Wright, Konseling Krisis Membantu Orang Tua Dalam Krisis dan Stres (Malang: Gandum Mas, 1985), 224.

${ }^{2}$ Stephen Tong, Keluarga Bahagia (Surabaya: Momentum, 2006), 100.
} 
Matius 19:8, "kata Yesus kepada mereka' karena ketegaran hatimu Musa menggizinkan kamu menceraikan isterimu, tetapi sejak semula tidaklah demikian. Allah menciptakan suami untuk istri dan mengginginkan agar mereka berdua memelihara sumpah mereka sampai mati, Yesus berkata dengan tegas" Apa yang telah dipersatukan Allah, tidak boleh diceraikan manusia" (Matius 19:6). Jadi bagaimanapun juga perceraian itu, bukanlah rancangan Allah yang sempurna untuk pernikahan. Memang Yesus ditanyakan masalah ini'" Apakah diperbolehkan orang menceraikan istrinya dengan alasan apasaja'? Jawab Yesus dengan tegas"' Aku berkata kepadamu: barang siapa menceraikan istrinya, kecuali karena Zinah, lalu kawin dengan perempuan lain, ia berbuatzinah. Matius19:9. Allah sendiripun membenci akan perceraian dan perzinahan, apalagi anak-anak dalam korban perceraian ${ }^{3}$

Allah tidak merancangkan perceraian melainkan Allah menciptakan suami istri untuk bersatu dan saling mencintai dan membangun hubungan keluarga yang harmonis, dan hubungan yang harmonis apabila orang tua mempunyai sikap yang baik terhadap anak-anak, karena kepribadian yang baik dari anak apabila ia melihat teladan dan sikap dari kedua orang yang yang baik, baik dari segi emosi, segi rohani, segi sosial dan segi mental.

\section{Pokok Masalah}

Dalam skripsi ini yang akan menjadi pokok masalah yaitu: sejauh mana pengaruh perceraian orang tua terhadap kepribadian anak usia 12-14 tahun di Panti Asuhan Cipta Pahlawan Makassar.

\section{Tujuan Penelitian}

Ada pun tujuan yang hendak dicapai pada akhir skripsi ini ialah mengetahui sejauh mana pengaruh perceraian orang tua terhadap kepribadian anak usia 12-14 tahun di Panti Asuhan Cipta Pahlawan Makassar.

\section{Manfaat Penelitian}

Beberapa manfaat dari penulisan skripsi ini sebagai berikut:

Pertama, sebagai bahan refleksi bagi kehidupan penulis secara pribadi dan untuk pelayanan kedepan.

Kedua, sebagai bahan kajian bagi pembaca dan panggilan untuk melayani anak-anak dari setiap segi masalah.

Ketiga, sebagai salah satu syarat untuk menyelesaikan studi strata satu (S1) di Sekolah Tinggi Theologia Jaffray Makassar.

\footnotetext{
${ }^{3}$ Glen H. Stassen dan David P. Gushee, Etika Kerajaan (Surabaya: 2008), 477.
} 


\section{Metode Penelitian}

Adapun metode penelitian yang digunakan dalam penulisan skripsi ini adalah metode kuantitatif, dengan teknik pengumpulan data adalah sebagai berikut:

Pertama, Penulis mengunakan kajian pustaka yaitu melalui buku-buku yang berkaitan dengan masalah pengaruh perceraian orang tua terhadap kepribadian anak.

Kedua, Penulis mengadakan observasi dilapangan, dengan cara menjalankan angket (tertutup) kepada anak-anak usia 12-14 tahun di Panti Asuhan Cipta Pahlawan Makassar. Tujuan menjalankan angket yaitu untuk memperoleh data yang lebih akurat tentang sejauh mana pengaruh perceraian orang tua terhadap kepribadian anak 12-14 tahun di Panti Asuhan Cipta Pahlawan Makassar.

Ketiga, Penulis mengadakan wawancara ${ }^{4}$ kepada Pembina Panti Asuhan Cipta Pahlawan untuk menguatkan data angket serta mengenal lokasi penelitian.

\section{Batasan Penelitian}

Adapun batasan penulisan skripsi lebih memfokuskan pada perceraian orang tua dan pengaruh pada kepribadian anak usia 12-14 tahun di Panti Asuhan Cipta Pahlawan Makassar.

\section{Kepustakaan}

Stassen, Glen H. dan David P. Gushee. Etika Kerajaan. Surabaya: Momentum., 2008.

Maiaweng, Peniel C. D. "Perceraian dan Pernikahan Kembali." Jurnal Jaffray 15, no. 1 (2017). http://dx.doi.org/10.25278/jj71.v15i1.237

Tong, Stephen. Keluarga Bahagia. Surabaya: Momentum, 2006.

Wijaya, Hengki (ed.). Metodologi Penelitian Pendidikan Teologi. Makassar: Sekolah Tinggi Theologia Jaffray, 2016.

Wright, Norman. Konseling Krisis Membantu Orang Tua Dalam Krisis dan Stres. Malang: Gandum Mas, 1985.

\footnotetext{
${ }^{4}$ Wawancara adalah cara memperoleh data dengan Tanya jawab dan bertatap muka dengan pihak yang diwawancarai. Hengki Wijaya (ed.), Metodologi Penelitian Pendidikan Teologi (Makassar: Sekolah Tinggi Theologia Jaffray, 2016), 24.
} 